\title{
Kajian Morphometri Pada Daerah Aliran Sungai (DAS) Batang Kuranji Terhadap Debit Banjir
}

\author{
Lusi Utama ${ }^{1}$ \\ Universitas Bung Hatta \\ e-mail: lusi_utamaindo115@yahoo.co.id \\ Amrizal Saidi $^{2}$ \\ Universitas Andalas \\ Isril Berd $^{3}$ \\ Universitas Andalas \\ Zuherna Mizwar ${ }^{4}$ \\ Universitas Bung Hatta
}

\begin{abstract}
ABSTRAK
Banjir bandang yang terjadi di Batang Kuranji tahun 2012 dimana Pemerintah Kota Padang mengklaim kerugian Rp 263,9 milyard, perlu dilakukan penelitian tentang morphometri yaitu parameter penyebab terjadinya banjir. Morphometri adalah jaringan phisik (DAS) secara kuantitatif yang berhubungan dengan geomorphologi yaitu luas DAS, bentuk DAS, kelerengan daerah, kerapatan drainase, penggunaan lahan, bentuk lahan, tinggi genangan dan gradien kecuraman sungai (kelerengan). Dengan mengetahui klasifikasi lahan (luas DAS) akan didapat pola aliran dan besarnya penyimpanan air. Ini akan mempengaruhi banyaknya hujan yang mengalir di permukaan tanah yang menyebabkan banjir. Bentuk DAS akan mempengaruhi konsentrasi hujan menuju outlet. Indeks kerapatan drainase menggambarkan kerapatan aliran sungai pada suatu DAS. Semakin tinggi angka kerapatan, resiko banjir semakin besar. Kecepatan aliran sungai dipengaruhi pada tingkat kecuraman sungai. Semakin besar kecuraman sungai, semakin tinggi kecepatan aliran demikian sebaliknya. Tinggi rendahnya kecepatan aliran sungai mempengaruhi kejadian banjir, apalagi bila dipengaruhi oleh debit air sungai yang besar. Penelitian dilakukan dengan cara deskriptif kualitatif yaitu tentang karakteristik DAS berdasar morphologi. Dengan menggunakan data curah hujan dari tahun 2005 sampai dengan tahun 2015. serta menggunakan DEM IFSAR dan Sofware ARGIS batang Kuranji termasuk daerah rawan banjir.
\end{abstract}

Kata kunci: Banjir, Morphometri, DAS, Curah Hujan

\begin{abstract}
Flash floods that occurred in Batang Kuranji in 2012 where the Government of Padang City claimed losses of Rp 263.9 billion, it is necessary to do research on the morphometry of the causes of flooding. Morphometry is a quantitative physical network (DAS) related to geomorphology ie watershed, watershed shape, slope area, drainage density, land use, landform, puddle height and steepness gradient of the river (slope). By knowing the classification of land (wide DAS) will get the flow pattern and the amount of water storage. This will affect the amount of rain that flows on the soil surface causing flooding. Watershed shape will affect the concentration of rain to the outlet. The drainage density index describes river flow density in a watershed. The higher the density, the greater the risk of flooding. River flow velocity is affected by river level steepness. The greater the steepness of the river, the higher the velocity of the flow and vice versa. The high and low flow rate of the river affects the occurrence of floods, especially when influenced by large river water discharge. The research was conducted by qualitative descriptive method that is about the characteristics of DAS based on
\end{abstract}

Jurnal Frontiers Volume 1 Nomor 1, April 201865

P-ISSN: 2621-0991 E-ISSN: 2621-1009 
morphology. By using rainfall data from 2005 until 2015 and using DEM IFSAR and ARGIS Software of Kuranji stem including flood prone area.

Keywords: Flood, Morphometry, Watershed, Rainfall

\section{PENDAHULUAN}

Perubahan iklim global yang terjadi di Kota Padang berdampak pada terjadinya akumulasi curah hujan yang tinggi. Dengan curah hujan tahunan yang relatif sama, namun dengan periode hujan yang singkat akan berdampak pada meningkatnya intensitas banjir yang terjadi. Parameter terjadi banjir adalah: kelerengan yang tajam, peruntukan tata ruang di dataran banjir yang tidak sesuai dengan fungsi lahan, belum adanya pola pengelolaan dan pengembangan dataran banjir, permukiman di bantaran sungai, sistem drainase yang tidak memadai, terbatasnya tindakan mitigasi banjir, kurangnya kesadaran masyarakat di sepanjang alur sungai, penggundulan hutan di daerah hulu, dan terbatasnya upaya pemeliharaan. Keadaan ini dapat dilihat pada kondisi eksisting di hulu Batang Kuranji seperti pada gambar 1

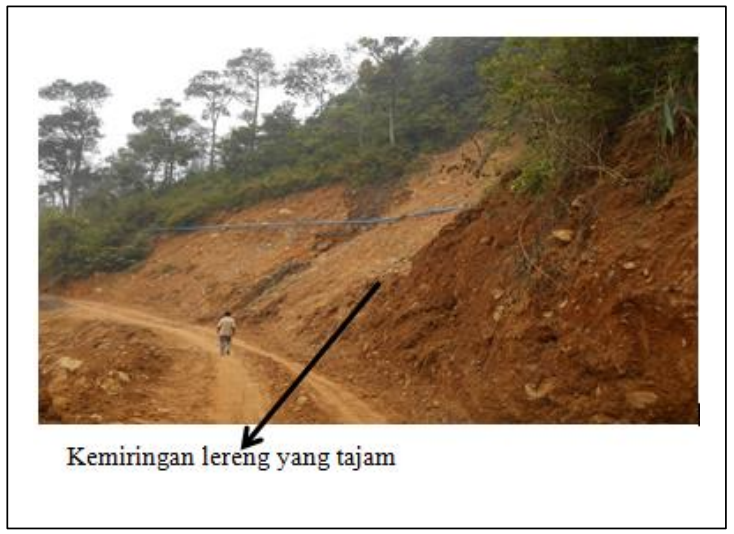

Gambar 1. Keadaan Hulu yang Tandus

Banjir adalah penggenangan akibat limpasan air keluar alur sungai karena debit sungai yang membesar tiba-tiba melampaui daya tampungnya, terjadi dengan cepat melanda daerah yang rendah, lembah sungai dengan membawa kayu, batuan, dan tanah dalam alirannya. Dengan pertambahan jumlah penduduk yang semakin pesat membawa dampak kepada peningkatan kebutuhan lahan dan permintaan akan pemenuhan kebutuhan pelayanan dan prasarana kota yang dapat berdampak menurunnya kualitas lingkungan seperti degradasi lingkungan dan bencana alam. Banjir bandang atau yang dikenal dengan galodo telah melanda Batang Kuranji, menurut ZahrulUmar pada hari Selasa tanggal 24 Juli 2012 dan hari Rabu tanggal 12 September 2012 pukul 16.30 WIB (Padang Ekspres 28 Juli 2012). Pemerintah Kota Padang mengklaim kerugian akibat banjir bandang Rp 263,9 Milyar Secara umum selain parameter penyebab banjir yang telah banyak diteliti, menurut Sutopo dan Van Zuldam ada beberapa faktoryang mempengaruhi terjadinya banjir, yaitu berupa morphometri, yang terdiri dari curah hujan, bentuk daerah aliran sungai (DAS), kerapatan drainase, kelerengan, penggunaan lahan, gradien sungai, bentuk lahan dan tinggi genangan. Dengan menggunakan peta Citra dan korelasi serta parameter morphometri akan ditentukan besarnya debit yang menyebabkan banjir di Batang Kuranji.

Permasalahan yang dibahas dalam kajian ini adalah kota Padang saat sekarang dengan intensitas hujan yang tinggi dan periode hujan yang singkat, mengalami banjir yang cukup besar. Untuk itu perlu ditinjau keadaan DAS Kuranji dalam menerima curah hujan.

Penelitian dilakukan dengan cara deskriptif kualitatif yaitu tentang karakteristik DAS berdasar morphologi pada DAS Batang Kuranji, terhadap debit. Debit yang terjadi akibat pengaruh 
morphometri adalah debit banjir. Hal ini agar dapat diketahui, parameter dari morphometri yang mengakibatkan banjir. Adapun metoda yang dilakukan adalah metoda survei dengan mengumpulkan data yaitu data curah hujan dari tahun 2005 sampai tahun 2015, data topografi serta peta bumi. Kumpulan data nantinya akan dianalisa (Arinkunto, 1996). Analisis DAS mengacu pada proses menggunakan DEM dan operasi data raster untuk menggambarkan daerah aliran sungai dan untuk mendapatkan fitur seperti sungai, jaringan sungai, daerah resapan, cekungan. Sebuah DAS besar dapat mencakup seluruh sistem sungai dalam DAS, mungkin ada aliran sungai kecil, satu untuk setiap anak sungai dalam sistem aliran. Data yang dibutuhkan:

1. Citra DEM IFSAR dengan resolusi 5 meter. IFSAR dengan Single Use Agustus 2011

\section{Sofware ARGIS}

Populasi adalah kumpulan satuan yang mempunyai karakteristik yang sama atau dianggap sama. Karakteristik ini dapat dilihat dalam bentuk ukuran tertentu (Yunus, 2006). Populasi dapat berupa lahan, yang mana lahan di permukaan bumi sangat beragam. Untuk itu dalam penelitian ini populasi lahan dibatasi dalam bentuk kemiringan lereng, kerapatan drainase, curah hujan, bentuk lahan, penggunaaan lahan, gradien sungai, ordo, bentuk DAS, dan tinggi genangan.

Penelitian ini dilakukan dengan tujuan sebagai rujukan bagi stakeholders dan pengambil kebijakan untuk dapat mengendalikan banjir, khususnya di daerah hilir yang berupa kawasan budidaya dan zona aman pemukiman, serta daerah hulu yang berupa hutan lindung untuk pemanfaatan hutan lindung.

Urgensi penelitian ini dapat dilihat dari beberapa pihak yaitu: a) Untuk Pemerintah Daerah: dalam rangka pengendalian pemanfaatan ruang, baik untuk kawasan lindung maupun budidaya, serta menjadi masukan dalam mekanisme perijinan pemanfaatan ruang di kawasan rawan bencana banjir maupun normalisasi pemanfaatan ruang di kawasan rawan bencana banjir yang telah dilandasi oleh mekanisme perijinan yang memadai serta sebagai acuan dalam penyusunan Peninjauan Kembali Rencana Tata Ruang Wilayah di daerahnya masing-masing. b) Untuk Pemerintah Daerah dan Masyarakat: sebagai acuan bersama dalam pengendalian perijinan dan normalisasi pemanfaatan ruang pada kawasan rawan bencana banjir, pada kawasan lindung maupun budidaya. c) Untuk pengembangan ilmu: Bagaimana karakteristik dari DAS sungai yang dapat menerima intensitas hujan yang tinggi sehingga tidak menimbulkan banjir yang merugikan harta dan jiwa.

Temuan dan pemecahan masalah yang ditargetkan dalam penelitian ini adalah mengetahui keadaan DAS Kuranji serta besarnya debit dalam menerima curah hujan. Selanjutnya akan dilakukan pengurangan resiko banjir baik berupa phisik dengan membuat bangunan pengendali banjir serta melakukan secara non phisik berupa aturan dalam peruntukan penggunaan lahan.

\section{KAJIAN TEORI}

\section{Parameter Morphometri}

Menurut Paimin et all, 2009, Soewarno, 1991, Rahayu et all 2009, parameter-parameter morphometri dapat dilihat pada tabel 1 .

\section{Pengertian: Morphometri DAS}

(Anonim, 2008), morphometri DAS merupakan ukuran kuantitatif karakteristik DAS yang terkait dengan aspek geomorfologi suatu daerah. Karakteristik ini terkait dengan proses air hujan yang 
jatuh di dalam DAS. Parameter tersebut adalah luas DAS, bentuk DAS, jaringan sungai, kerapatan aliran, pola aliran, dan gradien kecuraman sungai.

DAS adalah suatu daerah yang terhampar di sisi kiri dan dan kanan dari suatu aliran sungai, dimana semua anak sungai yang terdapat di sebelah kanan dan kiri sungai bermuara ke dalam suatu sungai induk. Seluruh hujan yang terjadi didalam suatu drainage basin, semua airnya akan mengisi sungai yang terdapat di dalam DAS tersebut. Oleh sebab itu, areal DAS juga merupakan daerah tangkapan hujan atau disebut catchment area. Semua air yang mengalir melalui sungai bergerak meninggalkan daerah daerah tangkapan sungai (DAS) dengan atau tanpa memperhitungkan jalan yang ditempuh sebelum mencapai limpasan (run off). (Mulyo, 2004). DAS juga dapat didefinisikan sebagai suatu daerah yang dibatasi oleh topografi alami, dimana semua air hujan yang jatuh didalamnya akan mengalir melalui suatu sungai dan keluar melalui outlet pada sungai tersebut, atau merupakan satuan hidrologi yang menggambarkan dan menggunakan satuan fisik-biologi dan satuan kegiatan sosial ekonomi untuk perencanaan dan pengelolaan sumber daya alam (Suripin, 2001). Morphomeri DAS adalah istilah yang digunakan untuk menyatakan keadaan jaringan alur sungai secara kuantitatif. keadaan yang dimaksud untuk analisa aliran sungai antara lain meliputi:

\section{a. Luas DAS}

DAS merupakan tempat pengumpulan hujan/presipitasi ke suatu sistem sungai. Luas daerah aliran dapat diperkirakan dengan mengukur daerah tersebut pada peta topografi. Garis batas antara DAS adalah punggung kontur/permukaan bumi yang dapat memisahkan dan membagi air hujan ke masing-masing DAS. Garis batas tersebut ditentukan berdasarkan perubahan kontur dari peta tofografi sedangkan luas DAS nya dapat diukur dengan alat planimeter. Skala peta yang digunakan akan mempengaruhi ketelitian perhitungan.

\section{b. Panjang dan Lebar DAS}

Panjang DAS adalah sama dengan jarak datar dari muara sungai ke arah hulu sepanjang sungai induk. Sedangkan lebar DAS adalah perbandingan antara luas DAS dengan panjang sungai induk.

\section{c. Kemiringan atau Gradien Sungai}

Gradien atau kemiringan sungai dapat diperoleh dengan persamaan sebagai berikut:

$$
\text { Gradien }=\text { Jarak Vertikal/Jarak }
$$$$
\text { Horisontal }=\Delta \mathrm{V} / \mathrm{L}
$$

Ket :

$\Delta \mathrm{V}=$ Beda tinggi antara hulu dengan hilir (m)

$\mathrm{L}=$ Panjang sungai induk (m)

Rumus lain menurut Rahayu et all, 2009 :

$\mathrm{Su}=\frac{h 85-h 10}{0.75 L b} \times 100$

$\mathrm{S}_{\mathrm{u}}=$ gradien sungai

h85 = elevasi pada titik sejauh $85 \%$ dari outlet

h10 $=$ elevasi pada titik sejauh $10 \%$ dari outlet

$\mathrm{Lb}=$ panjang sungai utama

\section{d.Orde \& Tingkat Percabangan Sungai}

1) Orde Sungai

Alur sungai dalam suatu DAS dapat dibagi dalam beberapa orde sungai. Orde sungai adalah posisi percabangan alur sungai di dalam urutannya terhadap induk sungai di dalam suatu DAS. Dengan demikian makin banyak jumlah orde sungai akan semakin luas pula DAS nya dan akan semakin panjang pula alur sungainya. Tingkat percabangan sungai (bufurcation ratio) adalah angka atau 
L. Utama ${ }^{1}$, A. Saidi ${ }^{2}$, I. Berd ${ }^{3}$,

Z. Mizwar ${ }^{4}$

indeks yang ditentukan berdasarkan jumlah alur sungai untuk suatu orde.

2) Tingkat percabangan sungai

Untuk menghitung tingkat percabangan sungai dapat digunakan rumus:
Jurnal Sains dan Teknologi, Universitas Negeri Manado http://ejournal.unima.ac.id/index.php/efrontiers

Tabel 1. Parameter-Parameter Morphometri

\begin{tabular}{|c|c|c|c|}
\hline Parameter & Klasifikasi & Kategori & Skor \\
\hline Hujan harian Maksimal (mm/hari) & $<20$ & Rendah & 1 \\
\hline \multirow[t]{4}{*}{ Pengaruh Alam (35\%) } & $21-40$ & Agak rendah & 2 \\
\hline & $41-75$ & Sedang & 3 \\
\hline & $76-150$ & Agak Tinngi & 4 \\
\hline & $>150$ & Tinggi & 5 \\
\hline Bentuk DAS & $<0.2$ & Lonjong & 1 \\
\hline \multirow[t]{4}{*}{ Pengaruh Alam (5\%) } & $0.21-0.40$ & Agak Lonjong & 2 \\
\hline & $0.41-0.60$ & Sedang & 3 \\
\hline & $0.61-0.80$ & Agak Bulat & 4 \\
\hline & $>0.80$ & Bulat & 5 \\
\hline Kerapatan Drainase $\left(\mathrm{km} / \mathrm{km}^{2}\right)$ & $<0.25$ & Jarang & 1 \\
\hline \multirow{4}{*}{ Pengaruh Alam (5\%) } & $0.26-8.50$ & Agak Jarang & 2 \\
\hline & $8.51-16.75$ & Sedang & 3 \\
\hline & $16.76-25$ & Agak Rapat & 4 \\
\hline & $>25$ & Rapat & 5 \\
\hline Lereng $(\%)$ & $>25$ & Sangat Curam & 1 \\
\hline \multirow[t]{4}{*}{ Pengaruh Alam (5\%) } & $15-25$ & Curam & 2 \\
\hline & $8-15$ & Terjal & 3 \\
\hline & $3-8$ & Landai & 4 \\
\hline & $0-3$ & Datar & 5 \\
\hline Penggunaan Lahan & Hutan & Rendah & 1 \\
\hline \multirow[t]{5}{*}{ Manajemen (40\%) } & Lindung/Konservasi & & \\
\hline & $\begin{array}{c}\text { Hutan } \\
\text { Produksi/Perkebunan }\end{array}$ & Agak Rendah & 2 \\
\hline & $\begin{array}{c}\text { Pekarangan / Semak/ } \\
\text { Belukar }\end{array}$ & Sedang & 3 \\
\hline & Sawah/Tegal - terasering & Agak Tinggi & 4 \\
\hline & Tegal / Pemukiman- kota & Tinggi & 5 \\
\hline Gradien Sungai (\%) & $<0.5$ & Rendah & 1 \\
\hline \multirow[t]{4}{*}{ Pengaruh Alam (10\%) } & $0.5-1.0$ & Agak Rendah & 2 \\
\hline & $1.1-1.5$ & Sedang & 3 \\
\hline & $1.6-2.0$ & Agak Tinggi & 4 \\
\hline & $>2.0$ & Tinggi & 5 \\
\hline Bentuk Lahan & Pegunungan, perbukitan & Rendah & 1 \\
\hline \multirow[t]{4}{*}{ Pengaruh Alam } & Kipas dan lahar & Agak Rendah & 2 \\
\hline & Dataran, teras & Sedang & 3 \\
\hline & $\begin{array}{c}\text { Dataran, teras } \\
(\text { lereng }<2 \%)\end{array}$ & Agak Tinggi & 4 \\
\hline & $\begin{array}{c}\text { Dataran aluvial, lembah } \\
\text { aluvial, jalur kelokan }\end{array}$ & Tinggi & 5 \\
\hline
\end{tabular}

Jurnal Frontiers Volume 1 Nomor 1, April 201869

P-ISSN: 2621-0991 E-ISSN: 2621-1009

Ket:

$\mathrm{Rb}=$ Indeks tingkat percabangan sungai

$\mathrm{Nu}=$ jumlah alur sungai untuk ordo ke $\mathrm{u}$

$\mathrm{Nu}+1=$ jumlah alur sungai untuk ordo ke $\mathrm{u}+1$ 
L. Utama ${ }^{1}$, A. Saidi ${ }^{2}$, I. Berd ${ }^{3}$, Z. Mizwar ${ }^{4}$
Jurnal Sains dan Teknologi, Universitas Negeri Manado http://ejournal.unima.ac.id/index.php/efrontiers

\begin{tabular}{lccc}
\hline Tinggi Genangan $(\mathrm{cm})$ & $<23$ & Rendah & 1 \\
\hline Pengaruh Alam & $24-47$ & Agak Rendah & 2 \\
\hline & $48-71$ & Sedang & 3 \\
\hline $72-95$ & Agak Tinggi & 4 \\
\hline & $>96$ & Tinggi & 5 \\
\hline
\end{tabular}

\section{e. Kerapatan sungai}

Kerapatan sungai adalah suatu angka indeks yang menunjukkan banyaknya anak sungai di dalam suatu DAS. Indeks tersebut diperoleh dengan persamaan sebagai berikut:

$$
\mathrm{Dd}=\mathrm{L} / \mathrm{A} .
$$

Ket:

$\mathrm{Dd}=$ indeks kerapatan sungai $(\mathrm{km} / \mathrm{km} 2)$

$\mathrm{L}=$ jumlah panjang sungai termasuk anakanak sungainya

$\mathrm{A}=$ Luas DAS $(\mathrm{km} 2)$

\section{f. Bentuk Daerah Aliran Sungai}

Pola sungai menentukan bentuk suatu DAS. Bentuk DAS mempunyai artipenting dalam hubungannya dengan aliran sungai, yaitu berpengaruh terhadap kecepatan terpusat aliran. Menurut Gregari dan Walling (1975), untuk menentukan bentuk
DAS dapat diketahui dengan menentukan nilai Rc nya dengan rumus:

$$
\mathrm{Rc}=4 \Pi \mathrm{A} / \mathrm{P} 2
$$

Ket:

$$
\begin{aligned}
& \text { Rc }=\text { Basin circularity } \\
& A=\text { Luas DAS }(\mathrm{m} 2) \\
& P=\operatorname{Keliling}(\mathrm{m}) \\
& \Pi=3,14
\end{aligned}
$$

Bentuk DAS mempengaruhi waktu konsentrasi air hujan yang mengalir menuju outlet. Semakin bulat bentuk DAS berarti semakin singkat waktu konsentrasi yang diperlukan, sehingga semakin tinggi fluktuasi banjir yang terjadi. Sebaliknya semakin lonjong bentuk DAS, waktu konsentrasi yang diperlukan semakin lama sehingga fluktuasi banjir semakin rendah.

\begin{tabular}{|c|c|c|c|}
\hline No & $\mathrm{Dd}$ & Kelas Kerapatan & Keterangan \\
\hline 1 & 0.25 & Rendah & $\begin{array}{l}\text { Alur sungai melewati batuan dengan resttistensikeras, maka } \\
\text { angkutan sendimen yang terangkat apada aliran sungai lebih } \\
\text { kecil jika dibandingkan pada alur sungai yang melewati } \\
\text { bantuan dengan restistensi yang lebih lunak, apabila kondisi } \\
\text { lain yang mempengaruhinya sama }\end{array}$ \\
\hline 2 & $0.25-10$ & Sedang & $\begin{array}{l}\text { sedang Alur sungai melewati batuan dengan resistensi yang } \\
\text { lebih lunak, sehingga angkutan sendimen yang terangkut } \\
\text { aliran akan lebih besar }\end{array}$ \\
\hline 3 & $10-25$ & Tinggi & $\begin{array}{l}\text { Alur sungai melewati batuan dengan resistensi yang lunak } \\
\text { sehingga angkutan sendimen yang terangkut aliran akan } \\
\text { lebih besar }\end{array}$ \\
\hline 4 & $>25$ & Sangat tinggi & $\begin{array}{l}\text { Alur sungai melwati batuan yang kedap air, keadaan ini akan } \\
\text { menunjukakan bahwa air hujan yang menjadikan aliran akan } \\
\text { lebih besar jika dibandingkan suatu derah dengan Dd rendah } \\
\text { melewati batuan yang permeabilitas besar }\end{array}$ \\
\hline
\end{tabular}

Bentuk DAS secara kuantitatif dapat diperkirakan dengan menggunakan nilai nisbah memanjang ('elongation ratio'/Re) dan kebulatan ('circularity ratio'/Rc).

Tabel 2. Arti Angka Indeks Kerapatan Sungai

Jurnal Frontiers Volume 1 Nomor 1, April 201870

P-ISSN: 2621-0991 E-ISSN: 2621-1009 


\section{g. Pola Pengaliran Sungai}

Sungai di dalam semua DAS mengikuti suatu aturan yaitu bahwa aliran sungai dihubungkan oleh suatu jaringan suatu arah dimana cabang dan anak sungai mengalir ke dalam sungai induk yang lebih besar dan membentuk suatu pola tertentu. Pola itu tergantung dari pada kondisi topografi, geologi, iklim, vegetasi yang terdapat di dalam DAS bersangkutan.

\section{h. Jaringan sungai}

Soewarno, 1991, Jaringan sungai dapat mempengaruhi besarnya debit aliran sungai yang dialirkan oleh anak-anak sungainya. Parameter ini dapat diukur secara kuantitatif dari nisbah percabangan yaitu perbandingan antara jumlah alur sungai ordo tertentu dengan ordo sungai satu tingkat di atasnya. Nilai ini menunjukkan bahwa semakin tinggi nisbah percabangan berarti sungai tersebut memiliki banyak anak-anak sungai dan fluktuasi debit yang terjadi juga semakin besar. Ordo sungai adalah posisi percabangan alur sungai di dalam urutannya terhadap induk sungai pada suatu DAS. Semakin banyak jumlah orde sungai, semakin luas dan semakin panjang pula alur sungainya. Ordo sungai dapat ditetapkan dengan metode Horton, Strahler, Shreve, dan Scheidegger. Namun pada umumnya metode Strahler lebih mudah untuk diterapkan dibandingkan dengan metode yang lainnya. Berdasarkan metode Strahler,alur sungai paling hulu yang tidak mempunyai cabang disebut dengan ordepertama (ordo 1), pertemuan antara orde pertama disebut orde kedua (ordo 2), demikian seterusnya sampai pada sungai utama ditandai dengan nomor ordo yang paling besar.

\section{i. Hujan harian maksimum}

Data curah hujan diambil dari tahun 2005 sampai tahun 2015.

\section{KLASIFIKASI BANJIR}

Dari parameter kerawanan banjir didapat klasifikasi banjir berdasar skor tiga variabel yang dibagi seperti tabel dibawah ini:

Tabel 3. Klasifikasi Banjir

\begin{tabular}{clc}
\hline No & \multicolumn{1}{c}{ Klasifikasi } & Skor \\
\hline 1 & Sangat rawan & $40-29.4$ \\
\hline 2 & Rawan & $29.3-18.7$ \\
\hline 3 & Tidak rawan & $18.6-8$ \\
\hline
\end{tabular}

\section{PEMBAHASAN}

Berdasarkan hasil perhitungan panjang dan kelas Orde sungai, menurut peta dan dengan menggunanakan ARGIS X.1, diperoleh panjang dan orde pada wilayah DAS Batang kuranji sebagai mana tabel 4.

Tabel 4. Panjang Dan Orde Pada Wilayah DAS Batang Kuranji

\begin{tabular}{lcc}
\hline Batang Kuranji & Jumlah & Total Panjang $(\mathrm{km})$ \\
\hline Orde 1 & 206 & 162.02 \\
\hline Orde 2 & 96 & 84.39 \\
\hline Orde 3 & 55 & 38.86 \\
\hline Orde 4 & 42 & 34,19 \\
\hline Orde 5 & 7 & 3.41 \\
\hline Grand Total & $\mathbf{4 0 6}$ & $\mathbf{3 2 2 , 8 7}$ \\
\hline
\end{tabular}

1. Luas Das Batang Kuranji $=177.89 \mathrm{~km}^{2}$

2. Panjang Sungai Utama Batang Kuranji $=30,90 \mathrm{~km}$

3. Kelerengan / Gradien Sungai

Kelerengan sungai dapat ditentukan dengan menggunakan metode "85 10 slope factor" dari Seyhan (1977) dengan rumus sebagai berikut :

$$
\mathrm{Su}=\frac{(\mathrm{h} 85-\mathrm{h} 10)}{(0,75 \mathrm{Lb})}
$$

Keterangan :

$\mathrm{Su}=$ Kemiringan/gradien Alur Sungai

Utama

h10 = Ketinggian titik yang terletak pada jarak 0,10 Lb

h85 = Ketinggian titik yang terletak pada jarak $0,85 \mathrm{Lb}$

$\mathrm{Lb}=$ Panjang Alur Sungai Utama

Jika

$\mathrm{h} 85=110 \mathrm{~m}$ 
$\mathrm{h} 10=10 \mathrm{~m}$

$(<0,5 \%$, termasuk daerah rendah) (skor 1$)$

$\mathrm{h} 85-\mathrm{h} 10=110-10=100 \mathrm{~m}$ atau $0,1 \mathrm{~km}$

$S u=\frac{0,1}{37,60}$

$=0,0026595$ atau $0,26595 \%$

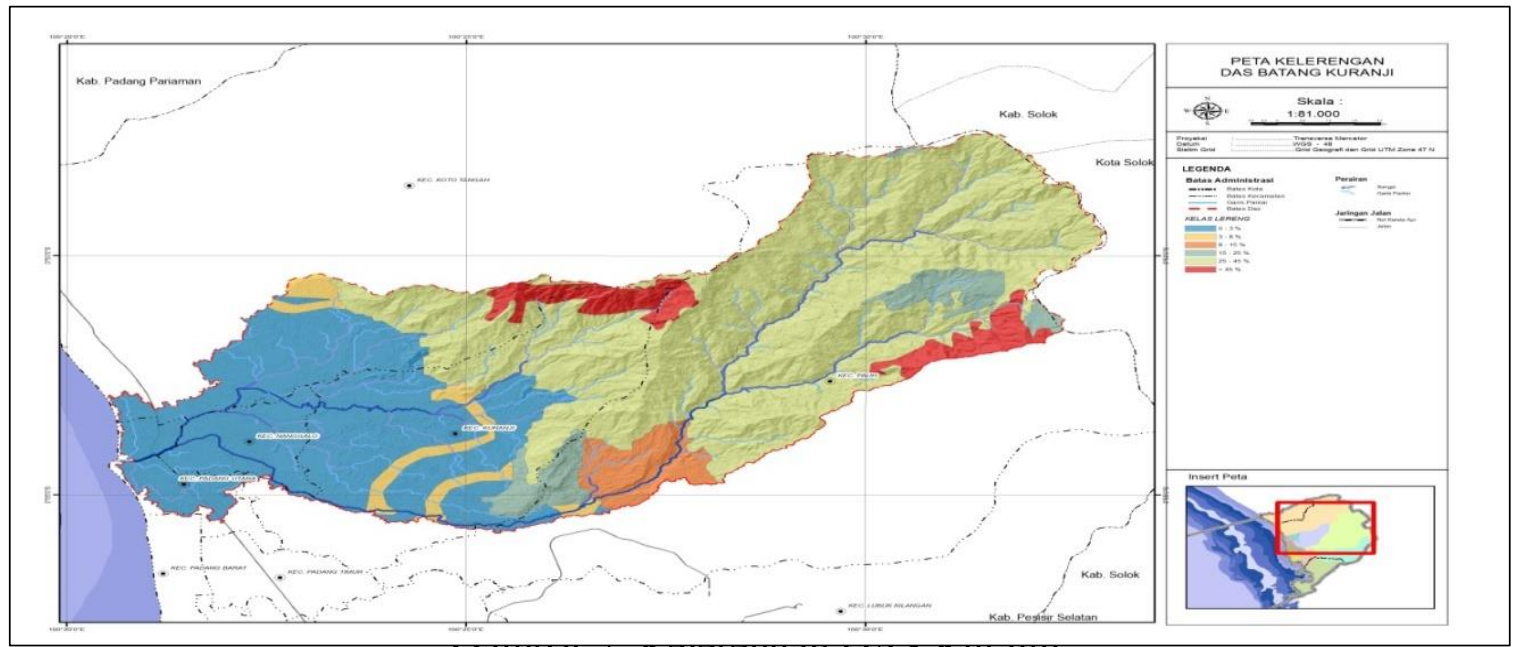

Gamival L. NeIcrengan DAN NuIanj!

4. Bifurcation Ratio (Rb)

Tabel 5. Orde dan Jumlah alur sungai( $\mathrm{Nu})$

Orde $\mathrm{Nu} \mathrm{Nu} /(\mathrm{Nu}+1)$

\begin{tabular}{ccc}
\hline 1 & $\mathbf{2 0 6}$ & 0.99 \\
\hline 2 & 96 & 0,99 \\
\hline 3 & 55 & 0,98 \\
\hline 4 & 42 & 0,98 \\
\hline 5 & 7 & 0,88 \\
\hline$\sum$ & 406 & 4,82 \\
\hline \multicolumn{2}{r}{$\mathrm{Rb}=\frac{\mathrm{Nu}}{(\mathrm{Nu}+1)}$} \\
& $\mathrm{Rb}=4.82=5$ (orde 5)
\end{tabular}

$\mathrm{WRb}=\frac{\sum \mathrm{Rbu} / \mathrm{u}+1(\mathrm{Nu}+\mathrm{Nu}+1)}{(\mathrm{Nu})}$

$\mathrm{WRb}=\frac{3,8 \times(406+411)}{406}$

$\mathrm{WRb}=\frac{3,8 \times 817}{406}$

$\mathrm{WRb}=\frac{3104,6}{406}$

$\mathrm{WRb}=7,64$

5. Circularity Ratio $(\mathrm{Rc})$ :

$$
\begin{array}{r}
\mathrm{Rc}=\frac{4 \pi \mathrm{A}}{\mathrm{P}^{2}} \\
\mathrm{~A}=177,89 \mathrm{Km} 2
\end{array}
$$

$\mathrm{P}=$ keliling DAS $=94,86 \mathrm{~km}$

$$
\begin{aligned}
& \mathrm{Rc}=\frac{\mathrm{A}}{\mathrm{Ac}} \\
& \mathrm{Ac}=\pi \mathrm{r}^{2} \\
& \begin{aligned}
2 \pi \mathrm{r}= & \text { keliling DAS } \\
\mathrm{r} \quad & =\frac{94,86}{2 \times 3,14}=\frac{94,86}{6,28} \\
& =15,10 \mathrm{~km} \\
& =\pi \mathrm{r}^{2} \\
& =3,14 \times(15,1)^{2} \\
\mathrm{Ac} \quad & 715,95 \mathrm{~km}
\end{aligned}
\end{aligned}
$$

Maka

Rc $=\frac{\mathrm{A}}{\mathrm{Ac}}=\frac{177,89}{715,95}=0,24$ (bentuk

Das agak lonjong) Skor 2

Pola Aliran Batang Kuranji: Dendritik

6. Kerapatan Drainase (Dd)

Soewarno, 1992, Untuk Panjang total Sungai induk dan anak sungai batang Kuranji $322,87 \mathrm{Km}^{2}$. Kerapatan sungai adalah suatu angka indeks yang menunjukkan banyaknya anak sungai di dalam suatu DAS.Indeks tersebut diperoleh dengan persamaan sebagai berikut: $\mathrm{Dd}=\mathrm{L} / \mathrm{A}$

Ket:

$\mathrm{Dd}=$ indeks kerapatan sungai $(\mathrm{km} / \mathrm{km} 2)$

$\mathrm{L}=$ jumlah panjang sungai termasuk anakanak sungainya. 
$\mathrm{A}=$ Luas DAS $(\mathrm{km} 2)$

Adapun karakteristik dari nilai indeks

kerapatan sungai (Dd) yaitu: $\mathrm{Dd}=$

$322,87 / 177,89=1.82$ (agak jarang) skor 2

Tabel 6. Kerapatan Drainase

\begin{tabular}{rrrrr}
\hline $\begin{array}{c}\text { DAS } \\
\text { Batang } \\
\text { Kuranji }\end{array}$ & $\begin{array}{c}\text { Panjang } \\
\text { Sungai }(\mathrm{km})\end{array}$ & $\begin{array}{c}\text { Sub } \\
\text { DAS }\end{array}$ & $\begin{array}{c}\text { Luas Sub DAS } \\
\left(\mathrm{Km}^{2}\right)\end{array}$ & $\begin{array}{c}\text { Dd } \\
\text { Kerapatan } \\
\text { Drainase })\end{array}$ \\
\hline 1 & 13,71753289 & 1 & 8,16 & 1,68 \\
\hline 10 & 47,0569605 & 10 & 46,82 & 1,01 \\
\hline 11 & 20,20599889 & 11 & 21,42 & 0,94 \\
\hline 2 & 12,57553094 & 2 & 5,68 & 2,21 \\
\hline 3 & 22,84188462 & 3 & 13,07 & 1,75 \\
\hline 4 & 3,655752564 & 4 & 3,37 & 1,08 \\
\hline 5 & 15,24711586 & 5 & 11,51 & 1,32 \\
\hline 6 & 36,71966418 & 6 & 22,41 & 1,64 \\
\hline 7 & 36,40189581 & 7 & 27,31 & 1,33 \\
\hline 8 & 6,708799195 & 8 & 6,58 & 1,02 \\
\hline 9 & 14,50001315 & 9 & 11,62 & 1,25 \\
\hline
\end{tabular}

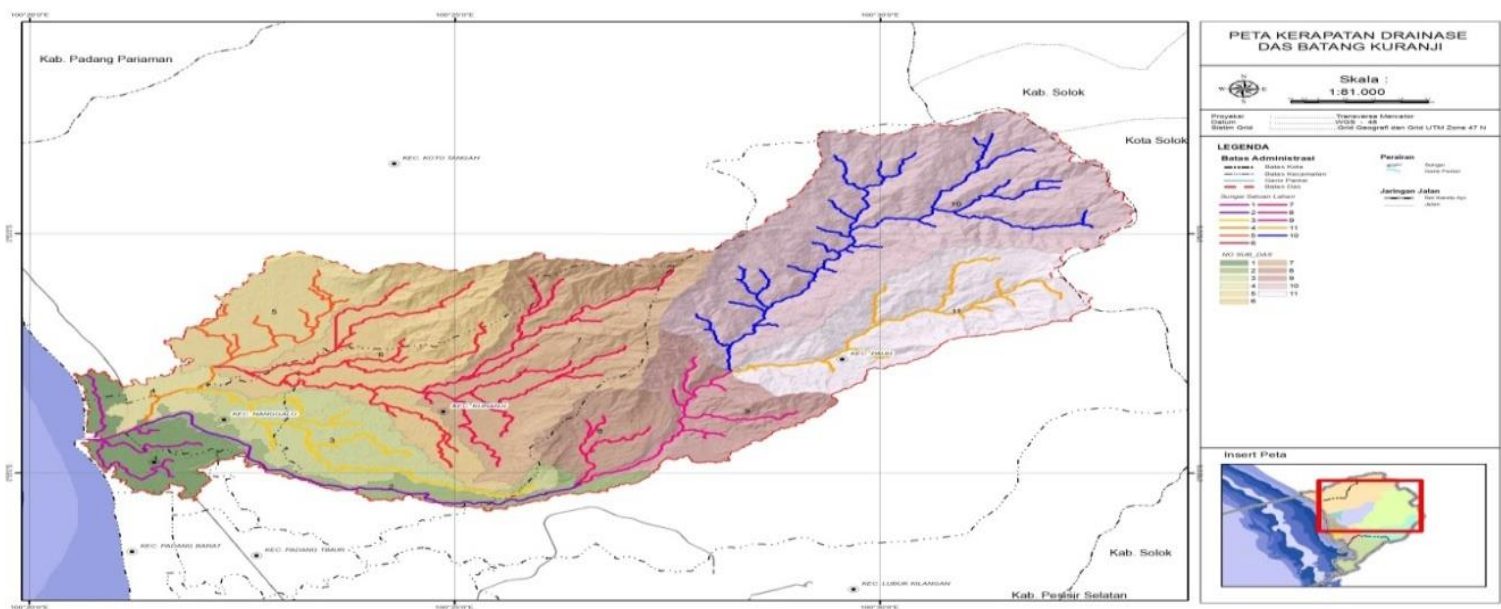

Gambar 3. Kerapatan Drainase 


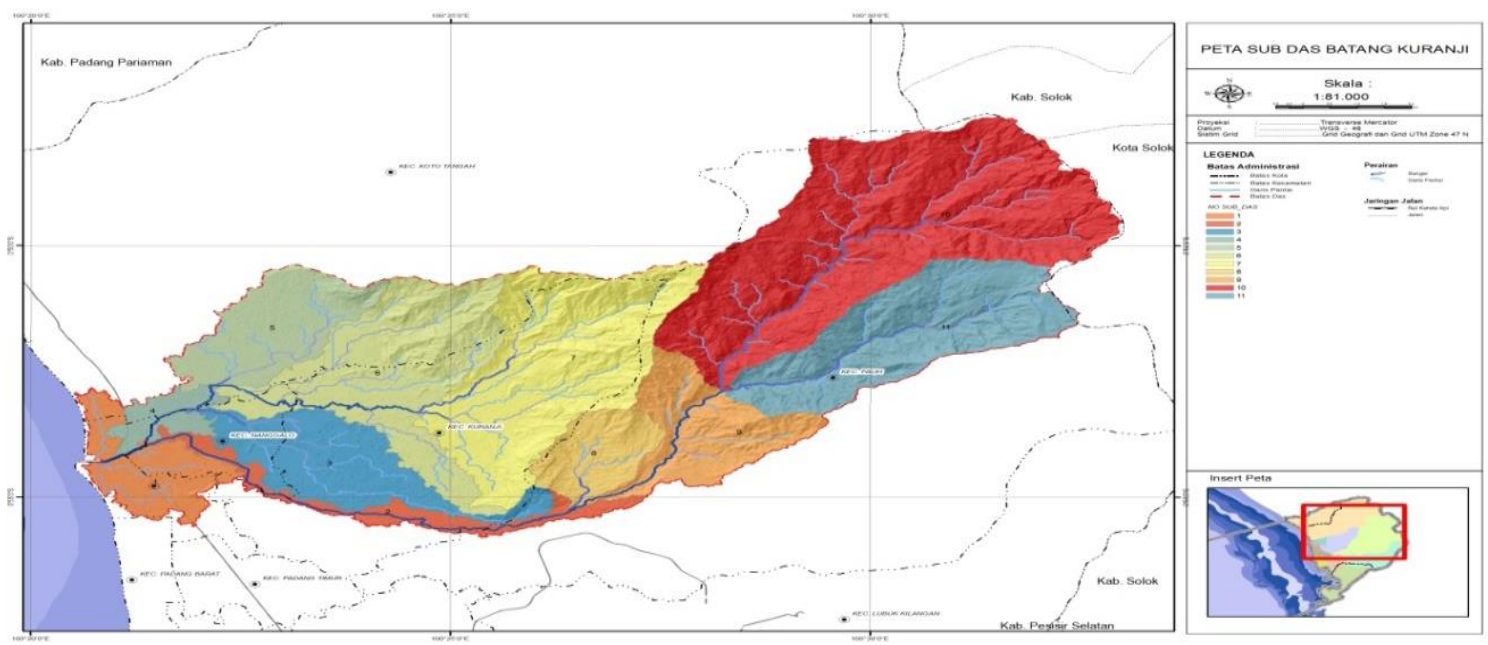

Gambar 4. Sub DAS Kuranji

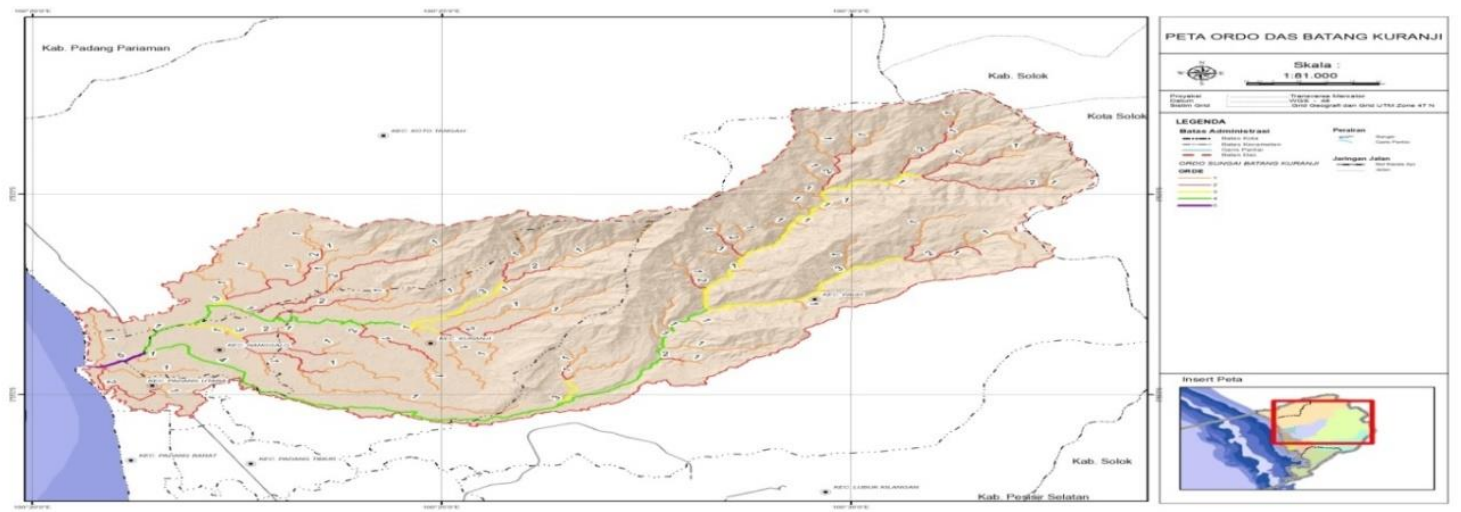

Gambar 5. Ordo DAS Kuranji

7.Rasio frekuensi ordo sungai $(\mathrm{F})$

Jumlah keseluruhan ordo sungai $=406$

Luas DAS $=177,89 \mathrm{Km} 2$

$$
\begin{aligned}
& F=\frac{\text { jumlah keseluruhan orde }}{\text { luas DAS }} \\
& F=\frac{406}{177,89} \\
& F=2,28
\end{aligned}
$$

\begin{tabular}{|c|c|c|}
\hline DAS & $\begin{array}{c}\text { Luas } \\
\left(\mathrm{Km}^{2}\right)\end{array}$ & Luas (ha) \\
\hline$\underline{\text { Batang Kuranj1 }}$ & 177,87 & $17 / 88,43$ \\
\hline $0-3 \%$ & 53,76 & 5374,13 \\
\hline $3-8 \%$ & 5,93 & 594,78 \\
\hline $8-15 \%$ & 6,48 & 648,49 \\
\hline $15-25 \%$ & 8,31 & 831,52 \\
\hline $25-45 \%$ & 94,63 & 9462,54 \\
\hline$>45 \%$ & 8,76 & 876,97 \\
\hline \multicolumn{3}{|c|}{$\begin{array}{l}\text { Dari kelerengan yang terbesar pada } 25 \\
5 \% \text { dengan luas } 94,63 \mathrm{~km}^{2} \text { (skor } 1 \text { ) dan } \\
3 \% \text { dengan luas } 53,76 \mathrm{~km}^{2} \text { (skor } 5 \text { ). } \\
\text { a-rata skor kelerengan } 3 .\end{array}$} \\
\hline
\end{tabular}

8. Kelerengan $(\%)$
Tabel 7. Kelerengan 
9. Penggunaan Lahan

Tabel 8. Penggunaan Lahan

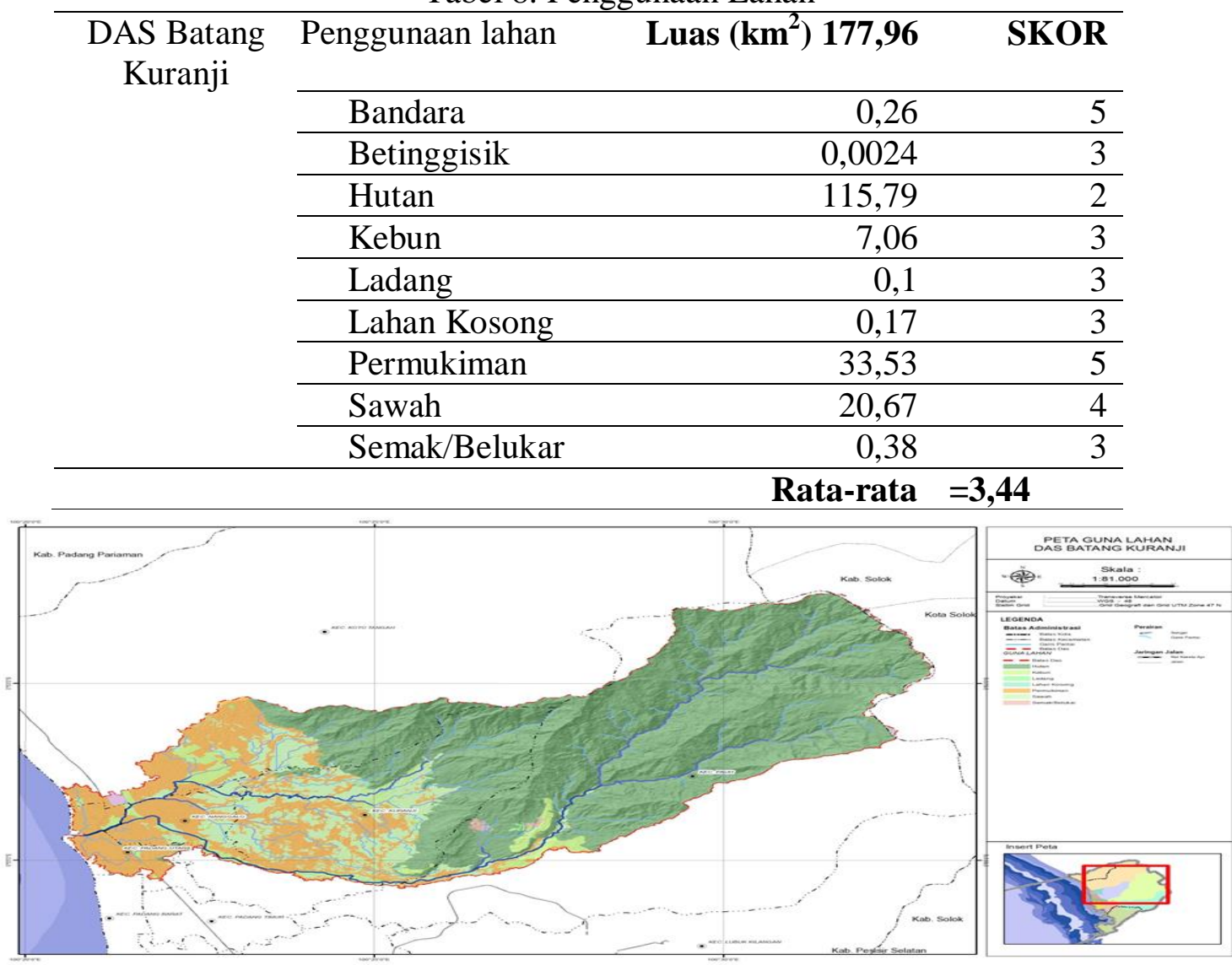

Gambar 6. Penggunaan Lahan

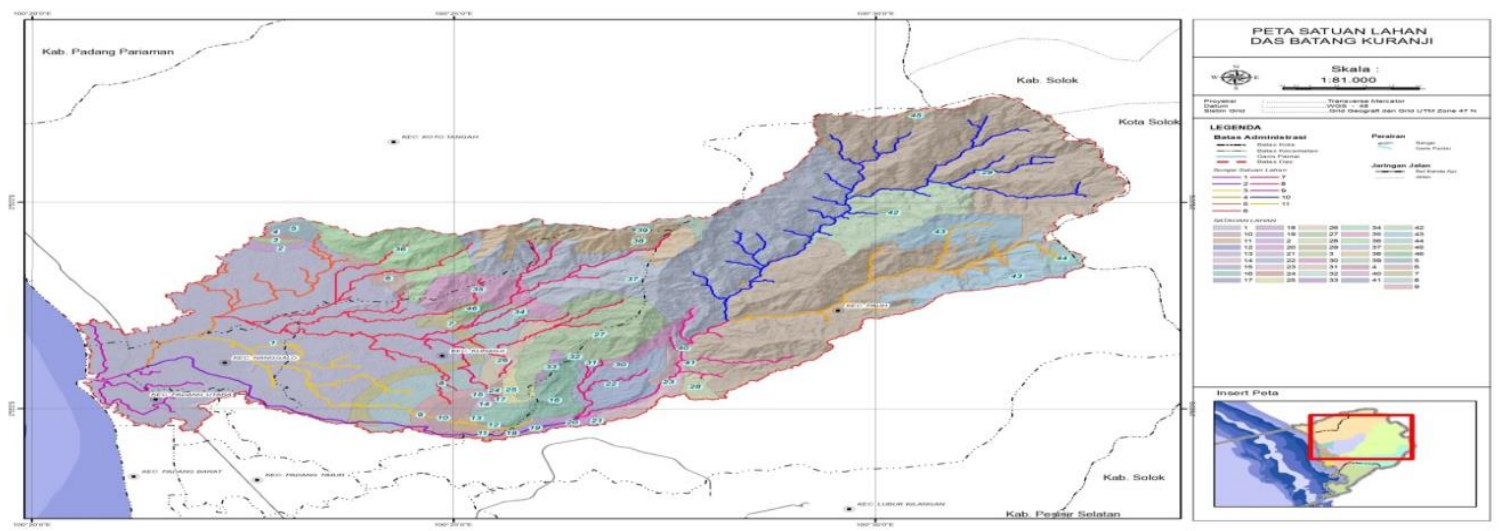

Gambar 7. Satuan Lahan

10. Curah hujan:

Dari Stasiun pencatatan curah hujan : maksimum adalah $193 \mathrm{~mm}$, termasuk skor Batu Busuk, Gunung Nago, Gunung Sarik 5 (iklim basah) dan Ladang Padi, curah hujan harian 


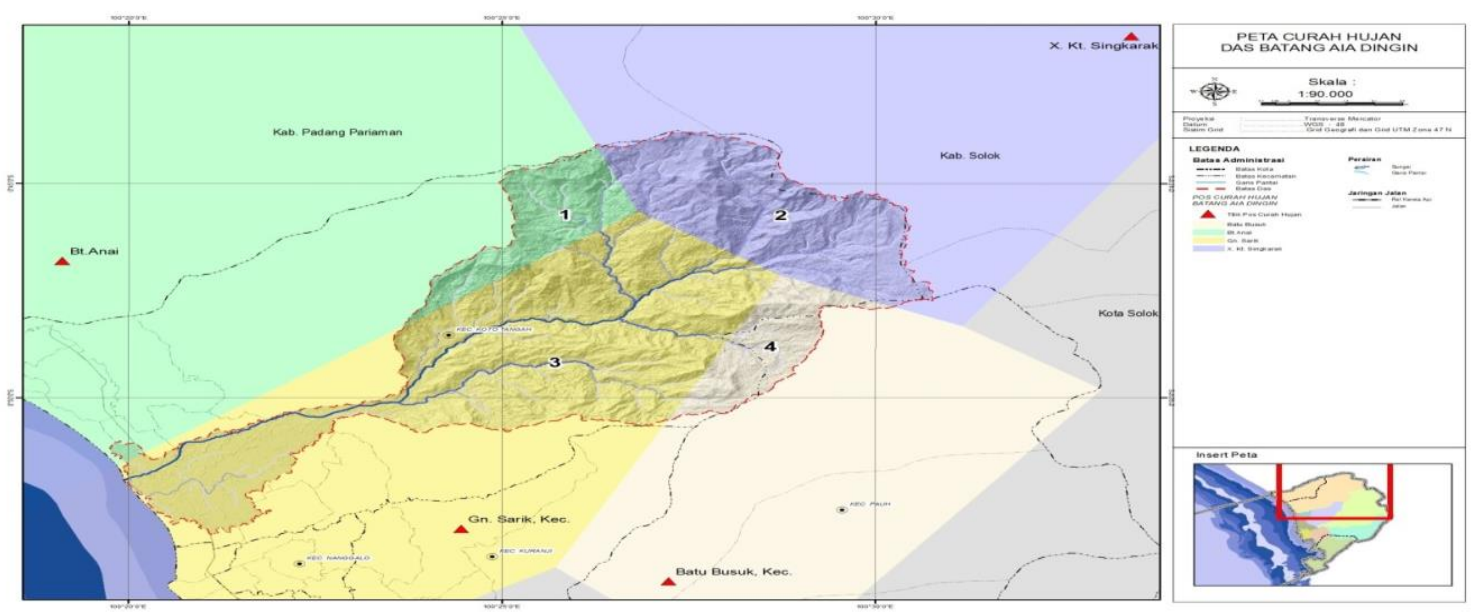

11. Bentuk lahan

Gambar 8. Stasiun Curah Hujan

Bentuk lahan adalah bentuk permukaan besar kerawanan banjir dibanding lahan bumi yang merupakan faktor penentu yang berbukit, berlereng terjal. Bentuk banjir. Bentuk lahan yang datar akan lebih lahan batang kuranji adalah:

Tabel 9. Bentuk Lahan

\begin{tabular}{llll}
\hline No & Bentuk lahan & Luas $\left(\mathrm{km}^{2}\right)$ & Skor \\
\hline 1 & Dataran aluvial & 53,75 & 1,51 \\
\hline 2 & Dataran teras (lereng <3\%) & 19,41 & 0,33 \\
\hline 3 & Kipas dan lahar & 14,31 & 0,16 \\
\hline 4 & Pegunungan & 8,76 & 0,05 \\
\hline 5 & Perbukitan & 81,64 & 0,46 \\
\hline & Total & 2,51 \\
\hline & & & \\
\hline & & & \\
& &
\end{tabular}

Gambar 9. Bentuk Lahan

\section{Tinggi Genangan}

$\mathrm{R}=$ curah hujan $=221,38 \mathrm{~mm}$

Luas catchment area $(\mathrm{A})=177,89 \mathrm{~km}^{2}$

Kemiringan Sungai $=\mathrm{S}=0,01$

Kecepatan aliran $(\mathrm{V})=4,54 \mathrm{~km} / \mathrm{jam}$

Waktu konsentrasi (t) $=6,81$ jam

Intensitas hujan $(\mathrm{I})=32,51 \mathrm{~mm} / \mathrm{jam}$

Debit sungai Batang Kuranji dengan

menggunakan rumus rasional:
$\mathrm{Q}=0,278$ C.I.A

didapat debit Batang Kuranji

$\mathrm{Q}=1125 \mathrm{~m}^{3} / \mathrm{detik}$

lebar rata-rata $70 \mathrm{~m}$, kedalaman air Batang

Kuranji $=2.5 \mathrm{~m}$. Penampang hilir

berbentuk trapesium $A=(b+h) \times h$

Sudut kemiringan sungai $=45^{0}$.

$\mathrm{P}=$ keliling basah $=\mathrm{b}+2 \mathrm{hV} 2$

$\mathrm{R}=\mathrm{A} / \mathrm{P}$ 
Dari penelitian lapangan, Batang Kuranji mempunyai dinding dan dasar ditumbuhi tanaman dan terdapatnya material, maka koefisien kekasaran $=0,050=\gamma \quad \mathrm{S}=$ kemiringan rata-rata batang Kuranji $=$ 0,05 . Untuk debit $\mathrm{Q}=1125 \mathrm{~m}^{3} /$ detik, maka nilai $\mathrm{y}=1,60$ meter, sedang kedalaman sungai rata-rata $=0.8 \mathrm{~m}$, maka terjadi banjir di daerah tengah dan hilir Batang Kuranji sebesar 80cm (Skor4)

Menentukan koefisien Chezy : $\mathrm{C}=87 /(1+$ $\gamma / \mathrm{VR}) \quad \mathrm{V}=\mathrm{CVRS}$

Tabel 10. Data koefisien Chezy

\begin{tabular}{|l|l|l|l|l|l|l|l|l|l|}
\hline $\mathrm{h}(\mathrm{m})$ & $\mathrm{A}\left(\mathrm{m}^{2}\right)$ & $\mathrm{P}$ & $\mathrm{R}$ & $\mathrm{VR}$ & $\gamma / \mathrm{VR}$ & $\mathrm{VRS}$ & $\mathrm{C}$ & $\mathrm{V}$ & $\mathrm{Q}$ \\
\hline 1 & 71 & 72,8 & 0,98 & 0,99 & 0,05 & 0,099 & 82,86 & 8,20 & 582,39 \\
\hline 1,5 & 107,25 & 74,2 & 1,45 & 1,2 & 0,04 & 0,12 & 83,65 & 10.07 & 1080,31 \\
\hline 2 & 144 & 75,6 & 1,90 & 1,38 & 0,042 & 0,14 & 83,49 & 11.51 & 1657,20 \\
\hline
\end{tabular}

Tabel 11. Parameter morphometri

\begin{tabular}{llll}
\hline No & Parameter & Skor & Total \\
\hline 1 & Kelerengan $=0,26595 \%$ (daerah rendah) & 1 & \\
\hline 2 & Rc $=0,24$ (bentuk DAS) agak lonjong & 2 & \\
\hline 3 & Kerapatan drainase Dd =1.82 (agak jarang) & 2 & 22,96 \\
\hline 4 & Lereng $(\%)$ (terjal ) & 3 & Rawan banjir \\
\hline 5 & Penggunaan lahan (sedang) & 3.44 & \\
\hline 6 & Curah hujan (tinggi) & 5 & \\
\hline 7 & Bentuk lahan (sedang) & 2,51 & \\
\hline 8 & Tinggi genangan ((agak tinggi) & 4 & \\
\hline
\end{tabular}

\section{PENUTUP}

\section{Kesimpulan}

Karakteristik Das Batang Kuranji skor 22,96; DAS Kuranji termasuk DAS Berdasar Morphometri disajikan pada rawan banjir tabel 12. Akibat dari morphometri: dengan

Tabel 12. Parameter morphometri

\begin{tabular}{llc}
\hline \multicolumn{1}{c}{ Parameter } & Batang Kuranji \\
\hline 1. & Banyak ordo & 5 \\
\hline 2. & Luas DAS & $177,89 \mathrm{~km}^{2}$ \\
\hline 3. & Panjang sungai utama & $30,90 \mathrm{~km}$ \\
\hline 4. & Panjang sungai beserta anak2nya & $229,60 \mathrm{~km}$ \\
\hline 5. Gradien sungai & 0,05 \\
\hline 6.Lebar rata-rata & 70 Meter \\
\hline 7.Kedalaman rata-rata & 2,50 meter \\
\hline 1. Debit & $1.125 \mathrm{~m}^{3} /$ detik \\
\hline 2. Kelerengan DAS & \\
\hline 0 - 3 $\%$ & $53,76 \mathrm{~km}^{2}$ \\
3 - 8 $\%$ & $5,93 \mathrm{~km}^{2}$ \\
8 - 15\% & $6,48 \mathrm{~km}^{2}$ \\
15 - 25 \% & $8,31 \mathrm{~km}^{2}$ \\
25 - 45 \% & $94,63 \mathrm{~km}^{2}$ \\
$>45 \%$ & $8,76 \mathrm{~km}^{2}$ \\
\hline
\end{tabular}

Jurnal Frontiers Volume 1 Nomor 1, April 201877

P-ISSN: 2621-0991 E-ISSN: 2621-1009 
L. Utama ${ }^{1}$, A. Saidi ${ }^{2}$, I. Berd ${ }^{3}$, Jurnal Sains dan Teknologi, Universitas Negeri Manado http://ejournal.unima.ac.id/index.php/efrontiers

\begin{tabular}{|c|c|}
\hline Grand Total & $177,89 \mathrm{~km}^{2}$ \\
\hline 3. Bentuk DAS (Rc) & 0,24 (agak lonjong) \\
\hline 4. Kerapatan Drainase (Dd) & $\begin{array}{c}1,82 \text { (agak jarang) kerapatan } \\
\text { sedang }\end{array}$ \\
\hline 5. Pola aliran & Dendritik \\
\hline 6. Penggunaan lahan & $\mathrm{Km}^{2}$ \\
\hline Bandara & 0,26 \\
\hline Betinggisik & 0,0024 \\
\hline Hutan & 115,79 \\
\hline Kebun & 7,06 \\
\hline Ladang & 0,1 \\
\hline Lahan Kosong & 0,17 \\
\hline Permukiman & 33,53 \\
\hline Sawah & 20,67 \\
\hline Semak/Belukar & 0,38 \\
\hline 7. Jumlah stasiun curah hujan & 4 \\
\hline 8. Curah hujan harian maksimum & $193 \mathrm{~mm}$ \\
\hline 9. Bentuk lahan & $\mathrm{Km}^{2}$ \\
\hline Dataran aluvial & 53,75 \\
\hline Dataran teras (lereng < 3\%) & 19,41 \\
\hline Kipas dan lahar & 14,31 \\
\hline Pegunungan & 8,76 \\
\hline Perbukitan & 81,64 \\
\hline 10. Tinggi genangan & $80 \mathrm{~cm}$ \\
\hline
\end{tabular}

\section{DAFTAR PUSTAKA}

Anonim. (2008). Memahami Bencana. Jakarta : Departemen Komunikasi dan Informatika Republik Indonesia.

Arikunto, S. (2006). Prosedur Penelitian,Jakarta : Bina Aksara

Asdak C. (2002). Hidrologi dan Pengelolaan Daerah Aliran Sungai. Yogyakarta: Gadjah Mada University Press.

Dinas kimpraswil, (1986), Pedoman penyusunan rehabilitasi lahan dan konservasi tanah

Hallaf, H.P., (2005). Geomorfologi Sungai dan Pantai. Jurusan geografi FMIPA UNM. Makassar.
Linsley RK, Kohler MA, Paulhus JLH. (1982). Hidrologi Untuk Insinyur.

Mulyo, (2004). Pengantar Ilmu Kebumian, Pengetahuan Geologi untuk Pemula. Bandung: Pustaka Setia

Paimin, (2009), Teknik Mitigasi Banjir dan Tanah Longsor, Balai Penelitian Teknologi Kehutanan Pengelolaan DAS Surakarta

Rahayu. Dkk. (2009). Banjir dan Upaya Penanggulangannya. Bandung : Pusat Mitigasi Bencana (PMB-ITB)

Sitanal Arsyad, Tahun (1989), Buku tentang konservasi tanah dan air

Soewarno, (1991). Hidrologi: Pengukuran dan Pengolahan Data Aliran Sungai (Hidrometri). Nova.Bandung 
L. Utama ${ }^{1}$, A. Saidi ${ }^{2}$, I. Berd ${ }^{3}, \quad$ Jurnal Sains dan Teknologi, Universitas Negeri Manado

Suripin (2001), Pelestarian Sumberdaya Tanah dan Air, Yogyakarta. Penerbit AndiYogyakartaFakultas Geografi UGM.

Yunus, H.S. (2005) "Manajemen Kota Perspektif Spasial", Penerbit Pustaka Pelajar, Yogyakarta 